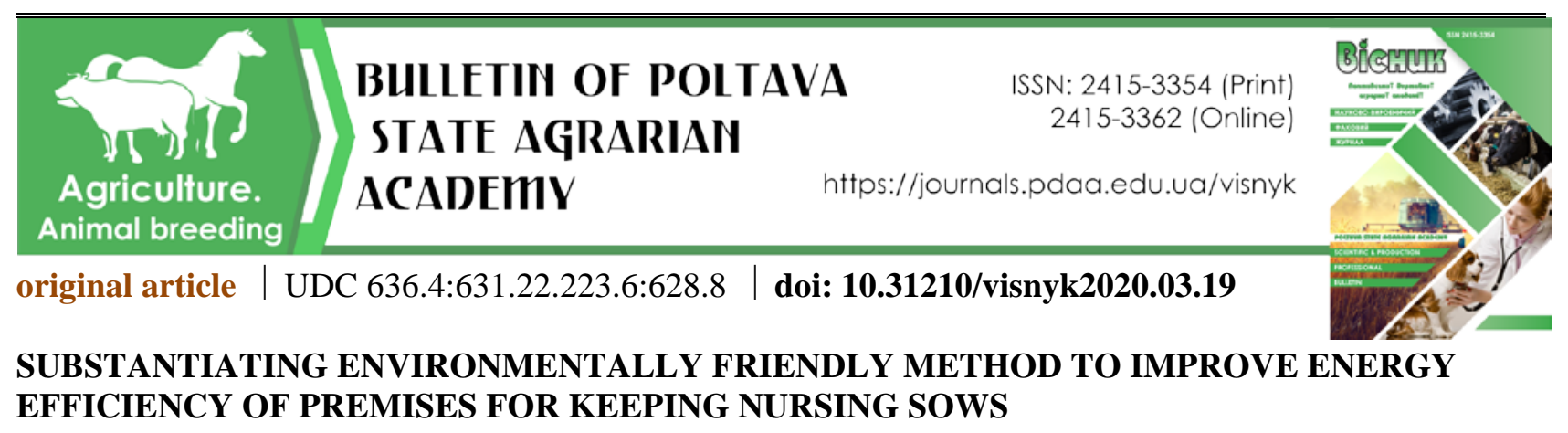

M. S. Nebylytsia

ORCID (D) 0000-0001-5509-8787

Cherkasy Experimental Station of Bio-Resources of the National Academy of Agrarian Sciences of Ukraine, 76, Pasteur str., Cherkasy, 18036, Ukraine

E-mail: nebilitsia@ukr.net

How to Cite

Nebylytsia, M. S. (2020). Substantiating environmentally friendly method to improve energy efficiency of premises for keeping nursing sows. Bulletin of Poltava State Agrarian Academy, (3), 174-182. doi: 10.31210/visnyk2020.03.19

Improving energy efficiency of sow-houses, in the process of designing the reconstruction, is of practical importance for production. This is due to the fact that in Ukraine there are pig farms and complexes, which were designed mainly according to construction standards of 1995. The aim of this study was to justify environmentally friendly method to increase energy efficiency of premises for milking sows and to develop an algorithm for its determining. General scientific (experiment, analysis, synthesis) methods were applied in solving the tasks. In addition, the main microclimate parameters and temperature of the building depending on the seasons of the year were investigated. Geometric, heat engineering and energy characteristics of the sow-house were determined. It was found that the pigsty was characterized by a high value $\left(0.54 \mathrm{~m}^{-1}\right)$ of compactness index. At the same time, the mass heat capacity of enclosing constructions, per $1 \mathrm{~m}^{3}$ of ventilated volume, made only $0.08 \mathrm{MJ}$ per $1^{0} \mathrm{~K}$, which indicated insufficient heat resistance of the house. As a result, in winter, at an average daily outdoor temperature of minus $2.9^{\circ} \mathrm{C}$, the indoor temperature dropped to $16.7^{\circ} \mathrm{C}$. Thus, it was $1.3^{\circ} \mathrm{C}$ below the minimum admissible value, according to the VNTP-AIC-02.05 standard. Performance indicators of milking sows showed a significantly higher value of the average live weight of piglets at weaning by $0.19 \mathrm{~kg}$ in spring and $0.29 \mathrm{~kg}$ in summer, as compared with winter ( $p<0.05$ and 0.01). At the same time, preservation of piglets litter before weaning was by 3.8-4.6\%. higher The economic efficiency of external wall insulation with ecologically safe Technofas effect heat-insulating material having a thickness of $50 \mathrm{~mm}$ was substantiated. An algorithm for determining energy efficiency the sow-house was developed. It is determined by the total annual consumption of energy, expressed in $k W \cdot h$, divided by the value of the ventilated volume and annual turnover rate ratio of one individual stall place. It has been determined that walls' thermal insulation of the heated pigsty contributes to improving its energy characteristics by $23.2 \%$. The estimated payback period in case of wall isolation with thermal insulation material will be 39.3 months. In addition, thermal insulation is environmentally important in saving 21.15 thousand $\mathrm{kW} / \mathrm{h}$ of specific heat consumption. This is equivalent to approximately 7.42 tons of conventional fuel.

Key words: substantiation, ecologically safe method, thermal insulation, premises of the sow-house, energy efficiency.

\title{
ЕКОЛОГІЧНО БЕЗПЕЧНИЙ СПОСІБ ПІДИЩЕННЯ ЕНЕРГОЕФЕКТИВНОСТІ ПРИМІЩЕННЯ ДЛЯ УТРИМАННЯ ПІДСИСНИХ СВИНОМАТОК
}

\section{М. С. Небилиця}

Черкаська дослідна станція біоресурсів НААН, м. Черкаси, Україна

Підвищення енергоефективності свинарників-маточників при плануванні реконструкції має практичне значення для виробництва. Це пов'язано з тим, що в Украӥні функиіонують свинарські 
ферми і комплекси, які проєктувалися переважно за будівельними нормами 1995 року. Метою роботи було обтрунтувати екологічно безпечний спосіб підвищення енергоефективності приміщення для утримання підсисних свиноматок та розробити алгоритм його визначення. У розв'язанні поставлених завдань застосовано загальнонаукові (експеримент, аналіз, синтез) методи досліджень. Визначено геометричні, теплотехнічні та енергетичні характеристики свинарника-маточника. Установлено, що приміщення характеризується високим значенням $\left(0,54 \mathrm{~m}^{-1}\right)$ показника компактності. Водночас теплоємність масова огороджувальних конструкиій у розрахунку на $1 \mathrm{~m}^{3}$ вентильованого об'єму становила 0,08 МДж на $1^{0} \mathrm{~K}$, ще свідчить про недостатню теплостійкість приміщення. У результаті за середньодобової температури зовнішнього повітря взимку мінус $2,9^{\circ} \mathrm{C}$ температура у приміменні знижувалася до $16,7^{\circ} \mathrm{C}$ або була на $1,3{ }^{\circ} \mathrm{C}$ нижче мінімально допустимого значення згідно з нормативом ВНТП-АПК-02.05. За таких температурних характеристик приміщення установлено вірогідно більше значення середньої живої маси поросяти при відлученні у весняний та літній періоди відповідно на 0,19 та 0,29 кг порівняно із зимовим періодом ( $p<0,05$ і 0,01). За такої умови збереженість приплоду поросят була більшою на 3,8-4,6\%. Обтрунтовано економічну ефективність зовнішнього утеплення стін екологічно безпечним теплоізоляційним матеріалом Технофас ефект товщиною 50 мм. Розроблено алгоритм для визначення енергоефективності свинарникаматочника. Ї̈ визначають за сумарним показником річного споживанням енергї̈, вираженої $у$

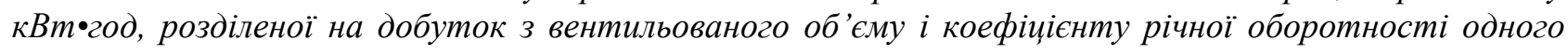
станкомісия. Визначено, що теплова ізоляиія стін опалюваного приміщення сприяе покращенню його енергетичних характеристик на 23,2 \% з терміном окупності 39,3 місяия. Крім иьього, теплова ізолячія відіграє важливе природоохоронне значення - економить 21,15 тис. кВт/год питомих витрат теплової енергії, що еквівалентно 7,42 т умовного палива.

Ключові слова: обтрунтування, екологічно безпечний спосіб, теплова ізолячія, приміщення свинарника-маточника, енергоефективність.

\section{ЭКОЛОГИЧЕСКИ БЕЗОПАСНЫЙ СПОСОБ ПОВЫШЕНИЯ ЭНЕРГОЭФФЕКТИВНОСТИ ПОМЕЩЕНИЯ ДЛЯ СОДЕРЖАНИЯ ПОДСОСНЫХ СВИНОМАТОК}

\section{Н. С. Небылица}

Черкасская опытная станция биоресурсов НААН, г. Черкассы, Украина

Целью статьи было обосновать экологически безопасный способ повышения энергоэффективности помещения для содержания подсосных свиноматок и разработать алгоритм его определения. $B$ решении поставленных задач применены общенаучные (эксперимент, анализ, синтез) методы исследований. Установлено, что свиноводческое помещение характеризуется показателем компактности, равным 0,54 $\mathrm{M}^{-1}$. В то же время, массовая теплоемкость ограждающих конструкций на 1 м $^{3}$ вентилируемого объема составила 0,08 МДж на $1^{0} \mathrm{~K}$, что свидетельствует о недостаточной теплостойкости помещения. Показатели продуктивности лактирующих свиноматок свидетельствуют о достоверно большем значении средней живой массы поросят при отъеме в весенний и летний период, соответственно на 0,19 и 0,29 кг в сравнении с зимним ( $p<0,05$ и 0,01). При этом сохранность приплода поросят была больше на 3,8-4,6\%. Разработан алгоритм определения энергоэффективности свинарника-маточника. Показано, что тепловая изоляция стен свинарника-маточника способствовует улучшению его энергетических характеристик на 23,2\% при полной окупаемости затрат за 39,3 месяия.

Ключевые слова: обоснование, экологически безопасный способ, тепловая изоляция, помещение свинарника-маточника, энергоэффективность.

\section{Ветуп}

Забезпечення свиней мікрокліматичними умовами згідно з нормами [1] дає змогу більшою мірою використовувати їхні продуктивні якості, що зумовлені спадковістю. При плануванні реконструкції підвищення енергоефективності функціонуючих свинарників-маточників має практичне значення для виробництва. Це пов'язано з тим, що в Україні функціонує багато ферм і комплексів, які проєктувалися, переважно, за будівельними нормами 1995 року [2], які не регламентували визначення енергоефективності.

Історичні довідки свідчать, що перші «енергоефективні споруди» з'явилися після світової кризи 1974 року як новий напрям у будівництві [3]. За літературними даними [4-8], проблеми енергозбереження та якості мікроклімату перебувають у центрі уваги фахівців галузі тваринництва і будівництва 


\section{СІЛЬСЬКЕ ГОСПОДАРСТВО. ТВАРИННИЦТВО}

всього світу, особливо впродовж останніх двох десятків років. Міжнародні проєкти, які підтримуються Європейською комісією, Програмами Tacis, Thermie, USAID та іншими організаціями, починаючи з 90-х років зробили енергоефективність достатньо відомим терміном.

За вимогою Директив 2006/32/СС та 2010/30/ЄС в Україні впроваджується Національний план дій 3 енергоефективності до 2020 року та затверджені технічні регламенти енергетичної продукції [9-13]. 2017 року набрали чинності ДБН В.2.6-31 «Теплова ізоляція будівель» [14] та ухвалений Закон України «Про енергетичну ефективність будівель» [15], які спрямовані на зменшення споживання енергії в будівлях. Потрібно наголосити, що дія вищезазначених будівельних норм і Закону стосовно енергоефективності не поширюється на будівлі сільськогосподарського призначення. Отже, це питання в Україні наразі вирішується лише в галузі цивільного будівництва та житлово-комунального господарства. Проте на необхідність впровадження енергозберігаючих технологій при проєктуванні та реконструкції тваринницьких підприємств наголошує низка зарубіжних [16-19] і вітчизняних [20-24] учених.

У розвинутих Свропейських країнах середній рівень споживання енергії в розрахунку на свиноматку на рік становить 983 кВт·год (за одержання 2,44 опоросів) [25] та 1163 кВт·год. (за одержання 24 поросят) [26] зі значним ступенем коливання. Крім того, для забезпечення оптимального мікроклімату $є$ метод розрахункового визначення показника енергетичної ефективності для житлової та громадської будівлі [14]. Він характеризує річну енергопотребу приміщення в опаленні, охолодженні та гарячому водопостачанні в розрахунку на одиницю опалюваної площі та кондиційованого об'єму.

Мета роботи - обгрунтувати екологічно безпечний спосіб підвищення енергоефективності приміщення для утримання підсисних свиноматок та розробити алгоритм його визначення.

Завдання дослідження:

- з'ясувати об'ємно-планувальні рішення, геометричні та теплотехнічні характеристики свинарника-маточника;

- визначити температуру огороджувальних конструкцій свинарника-маточника та вплив параметрів мікроклімату на продуктивність підсисних маток за періодами року;

- обгрунтувати екологічно безпечний спосіб підвищення енергоефективності свинарникаматочника та розробити алгоритм його визначення.

Розвязання цієї проблеми відповідає «Енергетичній стратегії України на період до 2035 року» [27].

\section{Матеріали і методи досліджень}

Аналітичні дослідження виконані у відділі тваринництва та виробництва екологічно чистої продукції Черкаської ДСБ НААН. Експериментальні дослідження проведені на фермі Черкаської ДСГДС ННЦ «IЗ НААН» у чотирирядному свинарнику-маточнику (75 індивідуальних станків) на тваринах червоної білопоясої породи. Використовували методики 3 дослідження мікроклімату свинарської будівлі [28] і температурних показників ії огороджувальних конструкцій за сезонами року згідно 3 наведеною схемою.

Схема досліду

\begin{tabular}{|c|c|c|c|c|}
\hline \multirow{2}{*}{ Показник } & \multicolumn{4}{|c|}{ Період року } \\
\hline & зимовий & весняний & літній & осінній \\
\hline $\begin{array}{l}\text { Найменування } \\
\text { та номер періоду }\end{array}$ & дослідний 1 & дослідний 2 & дослідний 3 & дослідний 4 \\
\hline $\begin{array}{l}\text { Параметри мік- } \\
\text { роклімату при- } \\
\text { міщення, } \\
{ }^{0} \mathrm{C}, \% \text {, Лк, pmm } \\
\end{array}$ & $\begin{array}{l}\text { температура, во- } \\
\text { логість, освітле- } \\
\text { ність, вміст } \mathrm{CO}_{2}\end{array}$ & $\begin{array}{l}\text { температура, во- } \\
\text { логість, освітле- } \\
\text { ність, вміст } \mathrm{CO}_{2}\end{array}$ & $\begin{array}{l}\text { температура, во- } \\
\text { логість, освітле- } \\
\text { ність, вміст } \mathrm{CO}_{2}\end{array}$ & $\begin{array}{l}\text { температура, во- } \\
\text { логість, освітле- } \\
\text { ність, вміст } \mathrm{CO}_{2}\end{array}$ \\
\hline $\begin{array}{l}\text { Температура } \\
\text { огороджень, }{ }^{0} \mathrm{C}\end{array}$ & $\begin{array}{l}\text { стіни, стеля, під- } \\
\text { лога, вікна, двері }\end{array}$ & $\begin{array}{l}\text { стіни, стеля, під- } \\
\text { лога, вікна, двері }\end{array}$ & $\begin{array}{l}\text { стіни, стеля, під- } \\
\text { лога, вікна, двері }\end{array}$ & $\begin{array}{l}\text { стіни, стеля, під- } \\
\text { лога, вікна, двері }\end{array}$ \\
\hline $\begin{array}{l}\text { Продуктивність } \\
\text { підсисних ма- } \\
\text { ток, кг, г, \% }\end{array}$ & $\begin{array}{c}\text { жива маса } 1 \text { голо- } \\
\text { ви, середньо- } \\
\text { добовий приріст, } \\
\text { збереження }\end{array}$ & $\begin{array}{c}\text { жива маса } 1 \text { голо- } \\
\text { ви, середньо- } \\
\text { добовий приріст, } \\
\text { збереження }\end{array}$ & $\begin{array}{c}\text { жива маса } 1 \text { голо- } \\
\text { ви, середньо- } \\
\text { добовий приріст, } \\
\text { збереження }\end{array}$ & $\begin{array}{c}\text { жива маса } 1 \text { голо- } \\
\text { ви, середньо- } \\
\text { добовий приріст, } \\
\text { збереження }\end{array}$ \\
\hline
\end{tabular}

У розв'язанні поставлених завдань застосовано загальнонаукові методи дослідження: експеримент, аналіз, синтез тощо. Для визначення геометричних показників свинарника-маточника використовували сертифікований прилад - лазерний вимірювач довжини Leica DISTO TM D210, серійний 


\section{СІЛЬСЬКЕ ГОСПОДАРСТВО. ТВАРИННИЦТВО}

№ 783648. Добовий моніторинг температури, відносної вологості, атмосферного тиску повітря та освітлення приміщення здійснювали приладом ЕАМ-5 (патент України на корисну модель № 108466). Температуру огороджувальних елементів будівлі визначали сертифікованим інфрачервоним термометром Flus IR-820, серійний № 2015085347.

За періодами року проводили дослідження середніх показників живої маси поросят (при народжені та відлученні у 30-денному віці), середньодобових приростів і відсотку збереження поросят до відлучення.

Тепловий баланс свинарника визначали за формулою:

$$
\mathrm{QT}=\Delta \mathrm{t}\left(\mathrm{G} \cdot 0,278+\sum \mathrm{KS}\right)+\mathrm{W} \Pi \mathrm{p},
$$

де $\mathrm{Q}_{\mathrm{T}}$ - вільне тепло, яке виділяють тварини за одну годину, Вт;

$\Delta \mathrm{t}$ - різниця між оптимальною температурою повітря всередині приміщення і середньою температурою зовнішнього повітря найхолоднішого місяця, ${ }^{0} \mathrm{C}$;

G - кількість повітря, що видаляється 3 приміщення вентиляцією або надходить до нього впродовж однієї години, кг;

0,278 - теплоємність повітря, Вт/кг/град;

K - коефіцієнт загальної теплопередачі через огороджувальні конструкції, Вт/год/м²/град;

$\mathrm{S}$ - площа огороджувальних конструкцій, $\mathrm{m}^{2}$;

$\sum$ - показник суми добутку K на S кожної окремої частини огороджень;

Wпр - витрата тепла на випаровування вологи 3 поверхні підлоги та інших огороджень приміщення, Вт/год.

Необхідні для розрахунку вентиляції та теплового балансу показники свиноматок і підсисних поросят брали з таблиць ВНТП-АПК-02.05. Товщину теплоізоляційного шару визначали за результатами розрахунку опору теплопередачі, згідно з розділом 5 ДСТУ Б В.2.6-189. Мінімально допустиме значення $\mathrm{R}_{q}$ min опору теплопередачі непрозорих огороджувальних стін встановлювали згідно з ДБН В.2.6-31 залежно від температурної зони експлуатації будівлі. Значення $\mathrm{R}_{\mathrm{q}}$ опору теплопередачі решти непрозорих огороджувальних конструкцій визначали згідно з ДБН В.2.6-31. Матеріали досліджень обробляли біометричними методами на комп'ютері з використанням програмного забезпечення Statistica 8. За результатами обробки даних визначали середню арифметичну величину (M), iї похибку (m), віргідність різниці між порівнюваними даними - за критерієм Стьюдента (td) і рівень ймовірності (p).

\section{Результати досліджень та їх обговорення}

Аналітичні дослідження об’ємно-планувальних рішень свідчать, що приміщення свинарника одноповерхове, прямокутне, 3 показником компактності $0,54 \mathrm{~m}^{-1}$. Несучі та огороджувальні елементи приміщення, на які припадає основне навантаження, виконані з таких будівельних матеріалів:

- фундамент - залізобетонні блоки;

- стіни - залізобетонні тришарові панелі суцільного перерізу (тип ЗНЦ), товщиною 120 мм (із зовнішнім і внутрішнім 35 мм армованим бетонним шаром і 50 мм теплоізоляційним 3 пінополістиролу між ними);

- стеля (сумісна 3 дахом) - стельові залізобетонні тришарові плити (тип 3НГ), з опалубкою дерев'яним брусом і теплоізоляційним шаром скловати (150 мм), покриті хвильовим шифером;

- підлога - керамзитобетон (індивідуальні станки) і бетон (кормові та гнойові проходи), товщиною 90-100 мм.

Спеціальне інженерне обладнання для обігрівання приміщення представлене піролізним котлом UTA-100U потужністю 100 кВт. Для локального обігрівання поросят індивідуальні станки були обладнані дерев'яними будиночками 3 електичними лампами інфрачервоного випромінювання потужністю 175 Вт. Вентиляція свинарника - природна припливно-витяжна. Для видалення гною приміщення обладнане двома скребковими транспортерами ТСН-160. Загальна площа засклених металопластикових вікон та внутрішніх брам і дверей становила відповідно: 42,7 та 20,7 м².

Під час проведення досліджень визначено основні геометричні і теплотехнічні характеристики свинарника-маточника. Згідно з об'ємно-планувальними рішеннями маса огороджувальних конструкцій і обладнання становила 82 кг у розрахунку на $1 \mathrm{~m}^{3}$ приміщення. Водночас теплоємність масова огороджувальних конструкцій у розрахунку на 1 м $^{3}$ вентильованого об'єму становила лише 0,08 МДж на $1^{0} \mathrm{~K}$, що свідчить про недостатню теплостійкість свинарника-маточника (табл. 1). 
СІЛЬСЬКЕ ГОСПОДАРСТВО. ТВАРИННИЦТВО

\begin{tabular}{|c|c|}
\hline \multicolumn{2}{|c|}{ 1. Геометричні і теплотехнічні характеристики приміщення } \\
\hline Найменування характеристик & Показник \\
\hline Довжина х ширина х висота, м & $71 \times 18 \times 3,10 / 4,50$ \\
\hline Об’єм приміщення без тамбурів, м ${ }^{3}$ & 4859 \\
\hline - в т.ч. на 100 кг живої маси свиней, м ${ }^{3}$ & $27,6-36,0$ \\
\hline Коефіцієнт компактності приміщення, м $^{-1}$ & 0,54 \\
\hline Загальна маса огороджувальних конструкій і обладнання, кг & 398800 \\
\hline - в т.ч. на одиницю об’єму, кг/м ${ }^{3}$ & 82 \\
\hline $\begin{array}{l}\text { Разом теплоємність масова огороджувальних конструкій і обладнання } \\
\text { на } 1^{0} \mathrm{~K}, \text { МДж }\end{array}$ & 363,0 \\
\hline $\begin{array}{l}\text { Всього теплоємність масова огороджувальних конструкій і обладнання } \\
\text { в розрахунку на одиницю об’єму на } 1^{0} \mathrm{~K}, \mathrm{MДж/ \textrm {M } ^ { 3 }}\end{array}$ & 0,08 \\
\hline \multicolumn{2}{|l|}{ Виділення тваринами теплоти всього, Вт/год.*: } \\
\hline - взимку, (на 100 кг живої маси 476,7) Вт/год. & 70550 \\
\hline - навесні-восени, $(455,7)$ Вт/год. & 67450 \\
\hline - влітку, $(436,6)$ Вт/год. & 64625 \\
\hline Повітрообмін за годину: - взимку $\left(30\right.$ м $^{3} / 100$ кг), кг & 5772 \\
\hline - навесні-восени $\left(45 \mathrm{~m}^{3} / 100\right.$ кг), кг & 8660 \\
\hline - влітку $\left(60 \mathrm{~m}^{3} / 100\right.$ кг), кг & 11544 \\
\hline
\end{tabular}

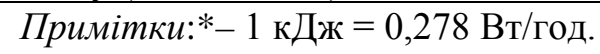

За таких характеристик приміщення в зимовий період року у разі зовнішньої середньодобової температури повітря мінус $2,9{ }^{0} \mathrm{C}$ температура у приміщенні знижувалася до $16,7{ }^{\circ} \mathrm{C}$, тобто була нижче мінімально допустимого значення на $1,3^{\circ} \mathrm{C}$. Коефіцієнт кореляції внутрішньої температури огороджень та зовнішньої температури довкілля дорівнював у межах $0,341-0,657 *(\mathrm{p}<0,05)$. Відносна вологість у приміщенні становила 87,4 \% або перевищувала норму на 17,4 \%. Температурний напір дорівнював $15,4{ }^{\circ} \mathrm{C}$, що підвищувало паро-проникність огороджувальних стін і негативно впливало на формування показника відносної вологості повітря у приміщенні. За таких обставин поросята піддавався деякому переохолодженню в період годування через підвищення конвекційних втрат тепла тілом.

Визначено, що більш комфортні та оптимальні величини температури і відносної вологості у приміщенні формуються у весняний та осінній період року. В літній період середньодобова температура повітря перевищувала максимально допустиме значення на 14,0 \%, а у спекотні дні - на 25,0 \%. Відносна вологість повітря переважала нормативний показник на 4,1 \%. Отже, параметр температури повітря можна оцінювати в цей період, як допустимий. Установлено значущий позитивний зв'язок між температурою повітря довкілля і свинарника-маточника взимку та влітку, з коефіцієнтами кореляції, відповідно $\mathrm{r}=0,672 *$ та $0,946^{*}$ (за $\mathrm{p}<0,05$ ).

За таких температурних характеристик приміщення установлено вірогідно більше значення середньої живої маси поросяти при відлученні у весняний та літній періоди відповідно на 0,19 та 0,29 кг порівняно із зимовим періодом ( $<<0,05$ i 0,01$)$. При цьому збереженість приплоду поросят була більшою на 3,8-4,6\% (табл. 2).

2. Вплив основних параметрів мікроклімату свинарника-маточника

на продуктивність підсисних маток залежно від періоду року, $n=20$

\begin{tabular}{|c|c|c|c|c|c|c|c|c|c|}
\hline \multirow[b]{2}{*}{$\begin{array}{l}\text { Період } \\
\text { року }\end{array}$} & \multicolumn{3}{|c|}{ Параметр: } & \multirow{2}{*}{ 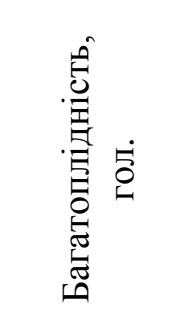 } & \multirow{2}{*}{ 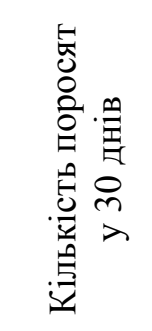 } & \multicolumn{2}{|c|}{$\begin{array}{l}\text { Маса } 1 \text { голови } \\
\text { (кг) при: }\end{array}$} & \multirow{2}{*}{ 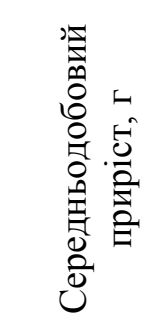 } & \multirow{2}{*}{ 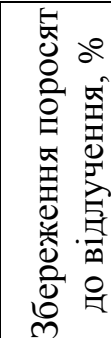 } \\
\hline & $\begin{array}{l}\circlearrowright \\
\bullet \\
\mapsto\end{array}$ & $\begin{array}{l}\partial^{0} \\
3\end{array}$ & 光 & & & 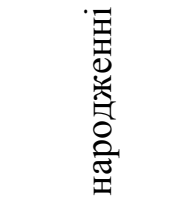 & 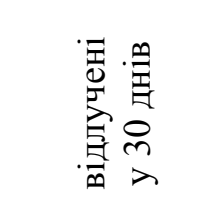 & & \\
\hline Зимовий & 16,7 & 88,1 & 51 & $10,2 \pm 0,36$ & $8,6 \pm 0,18$ & $1,21 \pm 0,02$ & $7,10 \pm 0,05$ & $198 \pm 2,3$ & 83,2 \\
\hline Весняний & 18,3 & 88,3 & 60 & $10,0 \pm 0,37$ & $8,8 \pm 0,20$ & $1,22 \pm 0,02$ & $7,29 \pm 0,05^{*}$ & $202 \pm 1,4$ & 87,8 \\
\hline Літній & 25,1 & 74,1 & 70 & $9,9 \pm 0,34$ & $8,5 \pm 0,21$ & $1,24 \pm 0,02$ & $7,39 \pm 0,10 * *$ & $205 \pm 2,6 *$ & 87,0 \\
\hline Осінній & 18,8 & 84,1 & 65 & $10,4 \pm 0,33$ & $9,0 \pm 0,21$ & $1,20 \pm 0,02$ & $7,21 \pm 0,09$ & $201 \pm 2,3$ & 87,6 \\
\hline
\end{tabular}

Примітки: ${ }^{*} \mathrm{p}<0,05 ; * * \mathrm{p}<0,01$. 


\section{СІЛЬСЬКЕ ГОСПОДАРСТВО. ТВАРИННИЦТВО}

Дані добового моніторингу температури стін приміщення в зимовий період свідчить про вірогідну позитивну кореляцію внутрішньої температури огороджень та зовнішньої температури довкілля $\left(\mathrm{r}=0,34-0,66^{*} ; \mathrm{p}<0,05\right)$. Температурний перепад на внутрішній і зовнішній поверхнях огороджувальних стін дорівнював $13,4-14,0{ }^{\circ} \mathrm{C}$ або в $4,1-4,4$ раза був більшим, ніж у теплий період року.

Зважаючи на вищенаведене, за існуючої потужності піролізного котла тепловий баланс свинарника-маточника був від'ємним (-189678 Вт/год.), у холодний період року. Розрахували можливість компенсації дефіциту теплової енергії через додаткову термоізоляцію огороджувальних стін. Для цього визначили необхідну товщину теплової ізоляції стін екологічно безпечним утеплювачем Технофас ефект. Дані розрахунків свідчать, що товщина цього утеплювача має становити не менше 50 мм. При цьому одержали значення опору теплопередачі огороджувальних стін на рівні 2,57 м² град/Вт, що відповідає вимогам ДБН В.2.6-31 (табл. 3).

\section{3. Розрахунок очікуваної ефективності теплоізоляції стін приміщення}

\begin{tabular}{|c|c|}
\hline Показник & Значення \\
\hline $\begin{array}{l}\text { Разом коефіцієнт теплоопірності } \mathrm{Rk} 1=(\mathrm{R} 1), \mathrm{m}^{2} \text { град/Вт (Коефіцієнт теплопере- } \\
\left.\text { дачі неутепленої стіни маточника } \mathrm{K}_{\mathrm{cr}}=1: 1,38=0,72 \mathrm{BT} / \mathrm{m}^{2} \cdot \mathrm{K}\right)\end{array}$ & 1,38 \\
\hline Коефіцієнт теплоопірності (R2) 50 мм утеплювача Технофас ефект, м² град/Вт & 1,19 \\
\hline $\begin{array}{l}\text { Разом коефіцієнт теплоопірності Rk2=(R1+R2), } \mathrm{m}^{2} г \text { град/Bт } \quad \text { (Коефіцієнт теп- } \\
\left.\text { лопередачі утепленої стіни } \quad K_{\mathrm{cr}}=1: 2,57=0,39 \mathrm{BT} / \mathrm{M}^{2} \cdot \mathrm{K}\right)\end{array}$ & 2,57 \\
\hline Співвідношення теплових витрат, Q1/Q2 = Rk2/ Rk1 & 1,86 \\
\hline Зниження витрат теплової енергії через стіни, \% & 86 \\
\hline Ефективність термоізоляції стін, \% $(0,27 \cdot 86)$ & 23,20 \\
\hline Разом економія питомої теплоти становитиме, тис. кВт/год. & 21,15 \\
\hline На суму (Е) за ціни на електроенергію 2,014 грн. за 1 кВт.год, тис. грн. & 42,60 \\
\hline Загальна вартість витрат на 1 м $^{2}$ теплоізоляції стін, грн. & 395,84 \\
\hline Всього витрат (С) на теплоізолцію стін площею 351 м², тис. грн. & 138,94 \\
\hline Термін окупності теплоізоляції $T=C / E=138,94 / 42,60$, міс. & 39,30 \\
\hline
\end{tabular}

Визначили очікувану ефективність заходу з утеплення стін за допомогою конструкції з вентильованою фасадною теплоізоляцією. Вона дорівнює 23,2 \% 3 терміном окупності 39,3 місяця. Крім того, захід із теплоізоляції має важливе природоохоронне значення - економить 21,15 тис. кВт/год питомих витрат теплової енергії, що еквівалентно 7,42 т умовного палива. Важливість цього питання підтверджується дослідженнями [29], які свідчать, що ціни на паливо, зокрема на нафтопродукти, будуть значно зростати впродовж найближчих десятиріч.

Методом оцінки приміщень щодо ефективності використання енергоресурсів є енергетична сертифікація, яка створює основу для оцінки та порівняння енергоспоживання різних типів приміщень для утримання тварин.

Узагальнюючи міжнародний та вітчизняний досвід з цього напряму діяльності, з'ясували, що за методологічну основу розрахунку енергетичної характеристики опалюваного свинарника-маточника потрібно брати витрати, що включають енергію не лише на потреби обігрівання та охолодження. Крім цього, потрібно враховувати енерговитрати, пов'язані з роботою систем вентиляції, освітлення, водопостачання та механізації процесів з приготування і роздавання кормів, видалення гною тощо.

Зважаючи на вищенаведене, ми розробили алгоритм для визначення енергоефективності свинарника-маточника. Він характеризує загальні річні енерговитрати, виражені у кВт·год та розділені на показник добутку об’єму приміщення і коефіцієнта річної оборотності одного станкового місця. Розраховується показник за такою формулою:

$$
E P t=\frac{\left(\sum R Q o+\Sigma R E n\right)}{(V b \cdot R o)}
$$

де $E P_{t}$ - енергоефективність приміщення, кВт·год / м $^{3}$;

$\sum$ - знак суми;

$R Q_{o}-$ загальне річне споживання паливної енергії, кКал (1 кКал $=1,163 \cdot 10^{-3}$ кВт·год);

$R E_{n}$ - загальне річне споживання електричної енергії, кВт· год;

$V_{b}$ - вентильований об'єм приміщення (без урахування тамбурів), м³;

$K_{o}$ - річний коефіцієнт оборотності одного станкомісця. 


\section{СІЛЬСЬКЕ ГОСПОДАРСТВО. ТВАРИННИЦТВО}

Загальне річне споживання електричної енергії розраховується за такою формулою:

$$
\sum R E n=(E o+E o b+E p r k+E v g+E v p+E s v)
$$

де $\sum R E_{n}$ це загальне річне споживання електроенергії (кВтөгод) на: $E_{o}$ - освітлення приміщення, $E_{o b}$ - обігрівання поросят, $E_{p r k}-$ приготування і роздавання корму, $E_{v g}-$ видалення гною, $E_{v p}-$ водопостачання, $E_{s v}$ - систему вентилювання.

Узагальнюючи результати проведених досліджень, необхідно зазначити, що термоізоляція огороджувальних стін $є$ лише одним із багатьох елементів термомодернізації свинарника-маточника, оскільки при плануванні реконструкції вона передбачає розроблення комплексу заходів щодо оптимізації енергетичної ефективності всіх інженерних систем приміщення.

Вищенаведена теза узгоджується 3 думкою інших учених, які зазначають, що подальший розвиток свинарства передбачає застосування ефективних типів забудови свинарських ферм із впровадженням енерго- і ресурсозберігаючих технологій утримання свиней [20, 22]. Застосування нових підходів і сучасних матеріалів при будівництві та реконструкції приміщень дає змогу підвищити коефіцієнт опору теплопередачі зовнішніх стін на $14 \%$, покрівлі на $10 \%$, вікон на $75 \%$, зі зменшенням загального енергоспоживання об'єкту на 33 \% [30]. Менше енергії витрачається на обігрів приміщення тепловим насосом порівняно з паливним котлом. Більше енергії потрібно для обігрівання поросят, якщо використовувати інфрачервоні лампи [26], ніж електрокилимки. Витік тепла в зимовий період року через одні нещільно встановлені двері еквівалентний отвору у стіні діаметром 200 мм [19]. Природна вентиляція приміщення не передбачає витрачання електроенергії, проте $є$ ненадійною. Механічна вентиляційна система потребує додаткових витрат електроенергії, які можна оптимізувати шляхом моделювання пікових навантажень чи автоматизованого керування сервомеханізмами за допомогою відповідних електронних датчиків [18]. Система вентиляції з механічним приводом при облаштуванні рекуперації тепла повітрям, що видаляється, може зменшити споживання теплової енергії на нагрівання свіжого повітря взимку до 55 \% [21]. Перевагою геотермічної системи вентиляції є незначне коливання температури (на $1-2{ }^{\circ} \mathrm{C}$ ) приточного повітря у приміщення впродовж доби, навіть за значних перепадів (на $15-20^{\circ} \mathrm{C}$ ) денних та нічних температур зовнішнього повітря. При цьому ефект охолодження сягає $10-12{ }^{\circ} \mathrm{C}$ і не залежить від показника відносної вологості зовнішнього повітря [16]. Енергозберігаючі пристрої для охолодження повітря в літню спеку можуть зменшити до 100 \% теплове навантаження на тварин. Інші заходи щодо адаптації, такі як зменшення щільності поголів'я та зміщення структури активності свиней на нічний час $є$ менш ефективними [31].

\section{Висновки}

Установлено, що теплова ізоляція стін свинарника-маточника екологічно безпечним утеплювачем Технофас ефект 50 мм товщини покращує енергетичну характеристику будівлі на 23,2 \% 3 терміном окупності 39,3 місяця. Водночас вона має важливе природоохоронне значення - економить 21,15 тис. кВт/год питомих витрат теплової енергії, що еквівалентно 7,42 т умовного палива. Отже, при плануванні реконструкції підвищення енергоефективності свинарських приміщень має практичне значення для виробництва в Україні. Це сприятиме підвищенню конкурентоздатності виробленої продукції свинарства будь-якого підприємства на внутрішньому чи міжнародному ринку.

Перспективи подальших досліджень полягають у розробленні більш ефективних екологічно безпечних способів термоізоляції свинарських приміщень при плануванні їхньої реконструкції.

\section{References}

1. Svynarski pidpryiemstva (kompleksy, fermy, nevelyki silski hospodarstva). VNTP-APK 02.05. Chynnyi vid 2006-01-01. (2006). Ministerstvo ahrarnoi polityky Ukrainy. Kyiv [In Ukrainian].

2. DBN V.2.2.1-95. Budynky ta sporudy. Budynky ta sporudy dlia tvarynnytstva. Chynnyi vid 1995-01-02. (1995). Kyiv: Derzhkommistobuduvannia Ukrainy [In Ukrainian].

3. Tabunshchikov, Yu., Brodach, M., \& Shilkin, N. (2003). Ehnergoehffektivnye kotly. Moskva: AvokPress [In Russian].

4. Tabunshchikov, Yu. (2008). Mikroklimat i ehnergosberezhenie: pora razobrat'sya v prioritetakh. Avok, 5, 4-11 [In Russian].

5. Mishurov, N., \& Kuzmina, T. (2004). Ehnergosberegayushchee oborudovanie dlya obespecheniya mikroklimata v zhivotnovodcheskikh pomeshcheniyakh. Moskva: Nauchnyj obzor [In Russian].

6. Bashchenko, M. I., Nebylytsia, M. S., \& Chernetsky, A. H. (2010). Osnovni pryntsypy rekonstruktsii tvarynnytskykh prymishchen dlia zastosuvannia resursozberihaiuchoi tekhnolohii vyrobnytstva svynyny: metodychni rekomendatsii. Cherkasy [In Ukrainian]. 
7. Aloyan, R. M., Fedosov, S. V., \& Oparina, L. A. (2016). Ehnergoehffektivnye zdaniya - sostoyanie, problemy i resheniya. Ivanovo: PreSSto [In Russian].

8. Maliarenko, V. A. (2006). Osnovy teplovoi fizyky budivel ta enerhozberezhennia. Kharkiv: SAHA [In Ukrainian].

9. Directive 2006/32/EC of the European Parliament and of the Council of 5 April 2006 on energy enduse efficiency and energy services and repealing Council Directive 93/76/EEC (Text with EEA relevance). Official Journal of the European Union. 27.4.2006. L 114/64.

10. Directive 2010/30/EU of the European Parliament and of the Council of 19 May 2010 on the indication by labelling and standard product information of the consumption of energy and other resources by energy-related products (Text with EEA relevance ). Official Journal of the European Union. 18.6.2010. L 153/1.

11. DSTU V.2.6-189:2013. Metody vyboru teploizoliatsiinoho materialu dlia uteplennia budynkiv. Chynnyi vid 2014-01-01. (2014). Kyiv: Minrehion Ukrainy [In Ukrainian].

12. DBN V.2.6-31:2006. Teplova izoliatsiia budivel. Chynnyi vid 2007-04-01. (2007). Kyiv: Ukrarkhbudinform [In Ukrainian].

13. DSTU ISO 50001: 2014. Enerhozberezhennia. Systemy upravlinnia enerhiieiu. Vymohy ta vkazivky shchodo vykorystannia (ISO 50001: 2011, IDT). Chynnyi vid 2015-01-01. (2015). Kyiv: Minekonomrovytku Ukrainy [In Ukrainian].

14. DBN V.2.6-31:2016 Teplova izoliatsiia budivel. Chynni vid 2017-05-01. (2017). Kyiv: Derzhavne pidpryiemstvo «Ukrarkhbudinform» [In Ukrainian].

15. Pro enerhoefektyvnist budivel: Zakon Ukrainy vid 22.06.2017 № 2118-VIII. (2017). Vidomosti Verkhovnoi Rady (VVR), 33, 5 [In Ukrainian].

16. Heisler, V. (2011). Enerhozberihaiuchi ventyliatsiini systemy na svynofermakh. Prybutkove Svynstvo, 3 (5), 54-57 [In Ukrainian].

17. Firfiris, V. K., Martzopoulou, A. G., \& Kotsopoulos, T. A. (2019). Passive cooling systems in livestock buildings towards energy saving: A critical review. Energy and Buildings, 202, 1. doi: 10.1016/j.enbuild.2019.109368.

18. Ecim-Djuric, O., \& Topisirovic, G. (2009). Energy efficiency optimization of combined ventilation systems in livestock buildings. Energy and Construction, 42, 8, 1165-1171. doi: 10.1016/j.enbuild.2009.10.035.

19. Clarke, S., \& Johnson, J. (2019). Improving Energy Efficiency in Livestock. Facilities Factsheet. 717. ag.info.omafra@ontario.ca.

20. Lymar, V. O., Voloshchuk, V. M., Khatko, I. V., \& Pidtereba, O. I. (2012). Peredovi tekhnolohii svynarstva ta yikh perevahy. Svynarstvo. Mizhvidomchyi Zbirnyk Naukovykh Prats Instytutu Svynarstva i APV NAAN., 60, 8-11 [In Ukrainian].

21. Tikhomirov, D., Vasilyev, A. N., Budnikov, D., \& Vasilyev, A. A. (2019). Energy-saving automated system for microclimate in agricultural premises with utilization of ventilation air. Wireless Netw. doi: 10.1007/s11276-019-01946-3.

22. Tkachuk, V., Kravchuk, N., Kilnitska, O., \& Shevchuk, K. (2016) Energy efficiency and conservation as a strategic vision of the agricultural entities' competitiveness increasing. Economic Annals-XXI. 160 (7-8). 71-76. doi: 10.21003/ea.V160-14.

23. Nebylytsia, M. S. (2019). Tekhniko-ekonomichne obgruntuvannia teploizoliatsii ohorodzhuvalnykh konstruktsii svynarskykh prymishchen. Svynarstvo. Mizhvidomchyi Zbirnyk Naukovykh Prats Instytutu Svynarstva i APV NAAN., 73, 48-57 [In Ukrainian].

24. Khazin, V. Y., Koshlatyi, O. B., \& Nesterenko, S. V. (2013). Zakhody z enerhozberezhennia pry proektuvanni ta ekspluatatsii tvarynnytskykh budivel. Enerhoefektyvnist $v$ Budivnytstvi ta Arkhitekturi, 4, 270-275 [In Ukrainian].

25. Marcon, M., (2009). Energy consumption in livestock housing (pigs). European Forum Livestock housing for the future. 2009, October 22/23- LILLE. France.

26. Hörndahl, T. (2008). Energy use in outbuildings. Alnarp Technical Report: (LTJ, LTV) Rural buildings and livestock, Sveriges lantbruksu Universalitet. Landskap trädgård jordbruk: rapportserie, 8, 43

27. Pro skhvalennia Enerhetychnoi stratehii Ukrainy na period do 2035 r. «Bezpeka, enerhoefektyvnist, konkurentospromozhnist» : Rozporiadzhennia Kabinetu Ministriv Ukrainy №. 605-r vid 18.08.2017. m. Kyiv [In Ukrainian].

28. Voloshuk, V. M., Nebylytsia, M. S., Vashchenko, O. O., \& Mazanko, M. O. (2016). Innovatsiinyi metod monitorynhu pokaznykiv mikroklimatu tvarynnytskykh prymishchen: metodychni rekomendatsii. Cherkasy [In Ukrainian]. 
29. Woods, J., Williams, A., Hughes, J. K., Black, M., \& Murphy, R. (2010) Energy and the food system. Philos Trans R Soc Lond B Biol Sci., 365 (1554), 2991-3006. doi: 10.1098/rstb.2010.0172.

30. Voloshchuk, V. M., Smyslov, S. Yu., \& Sokyrko, M. P. (2017). Netradytsiini rishennia prostorovoho planuvannia budivnytstva svynarskykh pleminnykh pidpryiemstv do 100 osnovnykh svynomatok. Naukovi Dopovidi NUBiP Ukrainy, 2 (66). doi: doi: 10.31548/ dopovidi2017.02.014 [In Ukrainian].

31. Schauberger, G., Mikovits, C., Zollitsch, W., Hörtenhuber, S., Baumgartner, J., Niebuhr, K., Piringer, M., Knauder, W., Anders, I., Andre, K., Hennig-Pauka, I., \& Schönhart, M. (2019). Global warming impact on confined livestock in buildings: efficacy of adaptation measures to reduce heat stress for growingfattening pigs. Climatic Change,156, 567-587. doi: 10.1007/s10584-019-02525-3.

32. Clarke, S., \& Johnson, J. (2019). Improving Energy Efficiency in Livestock. Facilities Factsheet. 717. ag.info.omafra@ontario.ca.

\section{Стаття надійшла до редакції 15.07.2020 р.}

Бібліографічний опис для цитування:

Небилиия М. С. Екологічно безпечний спосіб підвищення енергоефективності приміщення для утримання підсисних свиноматок. Вісник ПДАА. 2020. № 3. С. 174-182.

(C) Небиличя Микола Степанович, 2020 